\title{
Tax amnesty dan Implementasinya
}

\section{(Sebuah Pendekatan Eksploratif)}

\section{Nyoman Putra Yasa ${ }^{1}$ dan I Putu Wahyu Mandala ${ }^{2}$}

1Jurusan Akuntansi Program S1,Fakultas Ekonomi, Universitas Pendidikan Ganesha 2Jurusan Akuntansi Program S1,Fakultas Ekonomi, Universitas Pendidikan Ganesha ${ }^{*}$ Email corresponding author: putrayasanyoman11@gmail.com

\begin{abstract}
Abstrak
Tujuan dari penelitian ini adalah mengkaji pengimplementasian tax amnesty di Indonesia. Tax amnesty merupakan sebuah kebijakan lama yang coba kembali ditawarkan oleh pemerintah Indonesia setelah sebelumnya tahun 1964 dan 1984 pernah gagal untuk meningkatkan penerimaan negara.

Dalam pengimplementasiannya salah satu kelemahan Tax amnesty bila diterapkan di Indonesia adalah dapat mengakibatkan berbagai penyelewengan dan moral hazard karena sarana dan prasarana, keterbukaan akses informasi serta pendukung lainnya belum memadai sebagai prasyarat pemberlakuan tax amnesty tersebut. Dengan adanya payung hukum baru yaitu peraturan Dirjen Pajak Nomor 11/PJ/2016 tentang Pengaturan Lebih Lanjut mengenai pelaksanaan Undangundang Nomor 11 Tahun 2016 tentang Pengampunan Pajak (Tax amnesty). Peraturan baru DJP ini dibuat agar masyarakat memiliki azas keadilan bagi masyarakat. Aturan ini diharapkan dapat memperjelas aturan sebelumnya yang dinilai meresahkan masyarakat.

Penerapan tax amnesty berimplikasi terhadap beberapa hal diantaranya 1) Adanya peningkatan Wajib Pajak yang didorong adanya kebijakan tax amnesty,2) Adanya Peningkatan penerimaan pendapatan negara, yang disebabkan peningkatan Wajib Pajak karena adanya kebijakan tax amnesty,3)Terkait dengan pembangunan nasional, adaningkatan ya pepenerimaan pandapatan negara karena pajak akan membuat pembangunan lebih berjalan lancar dan diharapan bisa mempermudah masyarakat dan meningkatkan kesejahteraan.
\end{abstract}

Kata kunci: tax amnesty, Wajib Pajak, Implementasi 


\begin{abstract}
The purpose of this research is to examine the implementation of tax amnesty in Indonesia. Tax amnesty is an old policy that try again offered by the Government of Indonesia after 1964 and 1984, never failed to increase the acceptance of the State.

In pengimplementasiannya one of the weakness of the Tax amnesty when applied in Indonesia is can lead to a variety of abuses and a moral hazard because the facilities and infrastructure, information access and openness to the other supporters have not been adequate as a prerequisite the enactment of a tax amnesty. With the new law that is the regulatory umbrella of the Directorate General of Tax number 11/PJ/2016 about Further Arrangements regarding the implementation of law number 11 Year 2016 on the remission of tax (a Tax amnesty). The new rule was created in order for the community to have the principle of Justice for the community. This rule can clarify the previous rule diharpakan which rated troubling society.

The application of a tax amnesty to some of the things of which implicates 1) an increase in the taxpayer-driven policies tax amnesty .2) an increase in the receipt of State revenue, caused an increase in the Taxpayers because of the policy of tax amnesty, 3) related to national development, adaningkatan ya pepenerimaan pandapatan State because the tax will make the construction more running smoothly and diharapan can simplify and enhance the well-being of society

Keywords: implementation of tax amnesty, tax payers, implementation
\end{abstract}


Tax amnesty dan Implementasinya

\section{PENDAHULUAN}

Agung (2007) menyatakan bahwa pembangunan nasional yang berlangsung secara terus-menerus dan berkesinambungan selama ini, bertujuan untuk meningkatkan kesejahteraan baik materiil dan spiritual. Mewujudkan pembangunan nasional berjalan dengan baik diperlukan dana yang sangat besar. Salah satu usaha pemerintah dalam mewujudkan penerimaan negara guna menunjang pembangunan nasional adalah dengan menggali sumber dana yang berasal dari dalam negeri salah satunya adalah dari sektor pajak. Secara ekonomi, pemungutan pajak merupakan penerimaan negara yang digunakan untuk meningkatkan taraf hidup masyarakat. Untuk dapat meningkatkan taraf hidup masyarakat diperlukan peningkatan anggaran untuk dapat mendukung berbagai kegiatan pemerintah dalam memenuhi kesejahteraan masyarakat. Menurut Kementerian Keuangan dalam www.kemenkeu.go.id diakses 26 September 2016, target penerimaan dalam Anggaran Pendapatan Belanja Negara (APBN) 2016 adalah sebesar Rp 1.882,5 triliun, yang mana Rp 1.546,7 triliun atau 84,86\% bersumber dari sektor pajak.

Besarnya jumlah penerimaan dari sektor pajak, membuat DJP terus mencari solusi dan mengeluarkan kebijakan-kebijakan yang dapat menambah penerimaan dan menyelesaikan permasalahan terutama di bidang Perpajakan (Yasa dkk., 2016). Tahun 2016 DJP mengeluarkan program terbaru untuk memaksimalkan penerimaan negara di sektor pajak. Program terbaru yang dilaksanakan DJP merupakan program keberlanjutan dari program sebelumnya yang telah dilakukan kepada Wajib Pajak melalui pembinaan yang selanjutnya akan dilakukan penegakan hukum dalam perpajakan program pendisiplinan dan penegakan hukum kepada Wajib Pajak tahun 2016 disebut dengan Pengampunan Pajak atau dikenal dengan Tax amnesty.

Menurut Undang-Undang Republik Indonesia Nomor 11 Tahun 2016 tentang Pengampunan Pajak, Tax amnesty adalah penghapusan pajak yang seharusnya terutang, tidak dikenai sanksi administrasi perpajakan dan sanksi pidana di bidang perpajakan, dengan cara mengungkap harta dan membayar uang tebusan sebagaimana diatur dalam undang-undang. Program Tax amnesty ditujukkan untuk seluruh lapisan masyarakat yang berlaku sejak disahkan sampai dengan tanggal 31 Maret 2017, yang mana dalam pelaksanaanya program ini dibagi menjadi tiga periode yakni Periode I dilaksanakan dari tanggal diundangkan sampai dengan tanggal 30 September 2016, dilanjutkan periode II dari tanggal 1 Oktober 2016 sampai dengan tanggal 31 Desember 2016, dan periode III pelaksanaan dari tanggal 1 Januari 2017 sampai dengan tanggal 31 Maret 2017.

Sebelumnya Indonesia sudah pernah menerapkan tax amnesty pada tahun 1964 dan 1984. Namun, pelaksanaannya tidak efektif karena wajib pajak kurang merespon dan tidak diikuti dengan reformasi sistem administrasi perpajakan secara menyeluruh. Disamping itu peranan sektor pajak dalam sistem APBN masih berfungsi sebagai pelengkap saja sehingga pemerintah tidak mengupayakan lebih serius. Pada saat itu, penerimaan negara banyak didominasi dari sektor ekspor minyak dan gas bumi. Berbeda dengan sekarang, penerimaan pajak merupakan sumber penerimaan dominan negara dalam struktur APBN Pemerintah Indonesia.

Penelitian ini dilaksanakan bertujuan untuk melihat sejauh mana penerapan tax amnesty yang diterapkan oleh Pemerintah Indonesia dalam hal ini Direktorat Jendrel Pajak pada tahun 2016, selain untuk mengetahui tantangan, peluang, kelemahan dan keunggulan dalam penerapan tax amnesty. 


\section{TELAAH LITERATUR}

\section{Makna dan Fungsi Pajak}

Beberapa ahli memberikan batasan tentang pengertian pajak, diantaranya pengertian pajak yang dikemukakan oleh P.J.A. Andriani dalam Santoso (1998) menyebutkan bahwa:

"Pajak adalah iuran kepada negara (yang dapat dipaksakan) yang terutang oleh yang wajib membayar menurut peraturan-peraturan, dengan tidak mendapat prestasi kembali yang langsung ditunjuk, dan yang gunanya adalah untuk membiayai pengeluaran-pengeluaran umum berhubungan dengan tugas Negara yang menyelenggarakan pemerintah."

Mardiasmo (2011:1) menyatakan bahwa pajak adalah iuran rakyat kepada kas Negara berdasarkan undangundang yang dapat dipaksakan dengan tiada mendapat jasa timbal (kontraprestasi) yang langsung dapat ditujukan dan digunakan untuk membayar pengeluaran umum. Pajak memiliki dua fungsi utama, yaitu fungsi penerimaan (budgetair) dan fungsi mengatur (regular). Fungsi budgetair dimaksudkan bahwa pajak berfungsi sebagai sumber dana yang diperuntukkan bagi pembiayaan pengeluaran-pengeluaran pemerintah. Sedangkan fungsi reguler dimaksudkan sebagai alat untuk mengatur dan melaksanakan kebijakan di bidang sosial ekonomi.

\section{Sejarah Pengampunan Pajak (Tax amnesty di Indonesia)}

Pada mulanya pajak merupakan suatu upeti (pemberian secara suka rela) kepada raja, namun sifatnya yang dapat dipaksakan dan harus dilaksanakan hampir serupa dengan kewajiban pajak saat ini. Dalam perkembangannya di Indonesia, pajak telah ada pada zaman kolonial Belanda. Hal ini terlihat dari sudah adanya banyak undang-undang yang mengatur pembayaran pajak, seperti aturan bea materai, ordonasi pajak kekayaan, ordinasi pajak pembangungan, dan lain sebagainya.

Pada perkembangannya banyak bermunculan undang-undang mengenai perpajakan yang dirasa memberatkan masyarakat. Untuk menyikapi hal ini pemerintah yang dalam hal ini Direktorat Jendral Pajak (DJP) membuat kebijakan pengampunan pajak (tax amnesty) yang pertama di tahun 1964. Namun, pada tahun pertama dikeluarkannya kebijakan tax amnesty ini, masyarakat masih belum mengerti maksud pemerintah mengeluarkan kebijakan tax amnesty ini.

Di tahun 1984 pemerintah kembali mengeluarkan kebijakan pengampunan pajak ini. Pada tahun kedua ini kembali terjadi kegagalan, hal ini dikarenakan dalam pelaksanaannya wajib pajak kurang merespon dan tidak diikuti dengan reformasi sistem administrasi perpajakan secara menyeluruh. Disamping itu peran sektor pajak dalam sistem APBN masih berfungsi sebagai pelengkap saja sehingga pemerintah tidak mengupayakan lebih serius. Pada saat itu penerimaan negara banyak didominasi dari sektor ekspor minyak dan gas bumi.

Pada tahun 2008 direncanakan suatu kebijakan berupa Sunset Policy, yang sering disebut juga dengan soft amnesty. Sunset Policy adalah kebijakan pemberian fasilitas perpajakan, dengan memberikan penghapusan sanksi pajak administrasi perpajakan berupa bunga yang diatur dalam pasal 37A (Undang-undang Nomor 28 Tahun 2007). Sejak program Sunset Police diimplentasikan sepanjang tahun 2008 telah berhasil menambah jumlah NPWP (Nomor Pokok Wajib Pajak) baru sebanyak 5.653.128 NPWP, bertambahnya SPT (Surat Pemberitahuan Tahunan) tahunan sebanyak 804.814 SPT dan bertambahnya penerimaan PPh sebesar Rp 7,46 trilliun. Namun demikian, pada tahun 2009, jumlah wajib pajak yang tidak menyampaikan SPT mencapai 47,39\% 


\section{Tax amnesty dan Implementasinya}

dari total wajib pajak sebanyak 15.469 .590 jiwa. Hal ini membuktikan masih rendahnya tingkat kepatuhan dan kemungkinan wajib pajak kembali ke perilaku ketidak patuhan.

Di tahun 2016, pemerintah dalam hal ini DJP kembali lagi menerapkan kebijakan tax amnesty dengan tujuan utama menarik dana masyarakat demi menunjang pembangunan nasional, serta diharapkan mampu meningkatkan wajib pajak baru yang taat terhadap pajak. Demi mempermudah masyarakat dalam pemahaman mengenai tax amnesty, DJP mengambil keputusan untuk mengeluarkan Peraturan Dirjen Pajak Nomor 11/PJ/2016 tentang Pengaturan Lebih Lanjut mengenai pelaksanaan Undang-undang Nomor 11 Tahun 2016 tentang Pengampunan Pajak (Tax amnesty). Dengan adanya Undang-undang ini diharapkan masyakat bisa lebih paham tentang kebijakan pengampunan pajak ini serta lambat-laun masyarakat bisa mengerti pentingnya pembayaran pajak bagi pembangunan nasional.

\section{Tax amnesty}

Menurut Undang-Undang Republik Indonesia Nomor 11 Tahun 2016 Pasal 1 Ayat 1 tentang Pengampunan Pajak, Pengampunan Pajak adalah penghapusan pajak yang seharusnya terutang, tidak dikenai sanksi administrasi perpajakan dan sanksi pidana di bidang perpajakan, dengan cara mengungkap Harta dan membayar Uang Tebusan.

Wajib Pajak yang dimaksud dalam Undang-Undang Pengampunan Pajak Pasal 1 Ayat 2 adalah orang pribadi atau badan yang mempunyai hak dan kewajiban perpajakan sesuai dengan ketentuan perundang-undangan di bidang perpajakan. Harta yang dimaksud dalam Undang-Undang Pengampunan Pajak Pasal 1 Ayat 3 adalah akumulasi tambahan kemampuan ekonomis berupa seluruh kekayaan, baik berwujud maupun tidak berwujud, baik bergerak maupun tidak bergerak, baik yang digunakan untuk usaha maupun bukan untuk usaha, yang berada di dalam dan/atau di luar wilayah Negara Kesatuan Republik Indonesia.

Uang Tebusan dalam Undang-Undang Pengampunan Pajak Pasal 1 Ayat 7 adalah sejumlah uang yang dibayarkan ke kas negara untuk mendapatkan Pengampunan Pajak. Menurut Undang-Undang Pengampunan Pajak Pasal 2 Ayat 1, pengampunan pajak dilaksanakan berdasarkan asas kepastian hukum, keadilan, kemanfaatan, dan kepentingan nasional.

\section{METODE}

Untuk menganalisis implementasi tax amnesty di Indonesia digunakan metode kualitatif dengan pendekatan eksploratif deskriptif. Pendekatan eksploratif (Philip, Kotler \& Kevin L. Keller, 2006) adalah metode penelitian yang bertujuan menghimpun informasi awal yang akan membantu upaya menetapkan masalah dan merumuskan hipotesis. Sedangkan pendekatan dekriptif ada 45 netode penelitian yang bertujuan memaparkan (mendeskripsikan) sesuatu hal. Jadi pendekatan ini bertujuan untuk mendalami mengenai implementasi tax amnesty di Indonesia.

Untuk memperjelas gambaran mengenai peluang, tantangan, hambatan dan kelemahan penerapan tax amnesty di Indonesia digunakan SWOT analisis (Strenghts, Weaknesses, Opportunities dan Threats). Dari analisis SWOT ini dapat dilihat apa kelemahan dan kelebihan dari implementasi tax amnesty di Indonesia.

Bahan-bahan dan informasi berasal dari data sekunder yang didapat dari penggalian informasi dari berbagai sumber, bahan seminar, media masa, media elektronik, dan lain-lain serta didukung pula dengan kajian pustaka. 


\section{HASIL DAN PEMBAHASAN}

\section{Tingkat Kepatuhan Wajib Pajak}

Tingkat kepatuhan Wajib Pajak (WP) memegang peran penting terhadap keberhasilan pemerintah dalam menentukan besarnya penerimaan dari sektor pajak. Dengan semakin banyaknya WP, penerimaan dari sektor pajak akan meningkat dan membantu pembangunan nasional.

Hingga tahun 2015, Wajib Pajak (WP) yang terdaftar dalam sistem administrasi Direktorat Jenderal Pajak (DJP) mencapai 30.044.103 WP, yang terdiri atas 2.472.632 WP Badan, 5.239.385 WP Orang Pribadi (OP) Non Karyawan, dan 22.332.086 WP OP Karyawan. Hal ini cukup memprihatinkan mengingat menurut data Badan Pusat Statistik (BPS), hingga tahun 2015, jumlah penduduk Indonesia yang bekerja mencapai 102 juta orang, artinya baru sekitar 29,4\% dari total jumlah Orang Pribadi Pekerja dan berpenghasilan di Indonesia yang mendaftarkan diri atau terdaftar sebagai WP.

Di sisi yang berbeda BPS juga mencatat bahwa hingga tahun 2015, sudah beroperasi 23.941 perusahaan Industri Besar Sedang, 531.351 perusahaan Industri Kecil, dan 2.887.015 perusahaan Industri Mikro di Indonesia. Artinya, belum semua perusahaan terdaftar sebagai WP Badan. Hal ini membuktikan baik penduduk maupun perusahaan di Indonesia, ketaatan pajaknya masih rendah.

Rendahnya tingkat ketaatan pajak di Indonesia inilah yang mendorong pemerintah Indonesia dalam hal ini Direktorat Jendral Pajak memutuskan untuk kembali memperlakukan kebijakan pengampunan pajak (tax amnesty) pada tahun 2016. Tax amnesty diharapkan dapat meningkatkan jumlah Wajib Pajak, meningkatkan ketaatan masyarakat dalam pembayaran pajak, dan tidak dipungkiri dengan adanya tax amnesty diharapkan ada peningkatan dalam penerimaan Negara.

\section{Penerapan Tax amnesty Sebagai Alternatif}

Bagi banyak negara, pengampunan pajak (tax amnesty) seringkali dijadikan alat untuk menghimpun penerimaan negara dari sektor pajak (tax revenue) secara cepat dalam jangka waktu yang relatif singkat Program tax amnesty ini dilaksanakan karena semakin parahnya upaya penghindaran pajak. Kebijakan ini dapat memperoleh manfaat perolehan dana, terutama kembalinya dana yang disimpan di luar negeri, dalam kebijakan ini terdapat berbagai kelemahan. Dalam jangka panjang tax amnesty dapat berakibat buruk berupa menurunnya kepatuhan sukarela (voluntary compliance) dari wajib pajak patuh, bilamana tax amnesty dilaksanakan dengan program yang tidak tepat. Penulisan makalah ini memberikan gambaran mengenai pelaksanaan tax amnesty di negara Indonesia. Bagaimana kekuatan, kelemahan, peluang, serta tantangan yang dihadapi pemerintah dalam pelaksanaan tax amnesty ini.

Menurut Enste dan Schneider (2002) besarnya persentase kegiatan ekonomi bawah tanah (underground economy), di negara maju dapat mencapai 14 - 16 persen dari Produk Domestik Bruto (PDB), sedangkan di negara berkembang dapat mencapai 35 - 44 persen dari PDB. Kegiatan ekonomi bawah tanah ini tidak pernah dilaporkan sebagai penghasilan dalam formulir surat pemberitahuan tahunan (SPT) Pajak Penghasilan, sehingga masuk dalam kriteria penyelundupan pajak (tax evasion).

Penyelundupan pajak mengakibatkan beban pajak yang harus dipikul oleh para wajib pajak yang jujur membayar pajak menjadi lebih berat, dan hal ini mengakibatkan ketidakadilan yang tinggi. Peningkatan kegiatan ekonomi bawah tanah yang dibarengi dengan penyelundupan pajak ini sangat merugikan negara karena berarti hilangnya penerimaan pajak yang sangat dibutuhkan untuk membiayai program pendidikan, kesehatan dan 
program-program pengentasan kemiskinan lainnya. Oleh sebab itu, timbul pemikiran untuk mengenakan kembali pajak yang belum dibayar dari kegiatan ekonomi bawah tanah tersebut melalui program khusus yakni pengampunan pajak (tax amnesty).

\section{Peluang dan Tantangan Implementasi Tax amnesty di Indonesia}

Ada beberapa langkah yang ditempuh pemerintah Indonesia khususnya Direktorat Jendral Pajak guna meningkatkan penerimaan negara dari sektor pajak, antara lain melaksanakan program Sensus Pajak Nasional.. Selain itu melakukan penyempurnaan peraturan untuk menangani tindakan penghindaran pajak (tax avoidance), tindakan penggelapan pajak melalui transfer pricing, dan pengenaan pajak final.

Salah satu bentuk upaya atau inovasi lain dalam perpajakan yang berguna meningkatkan penerimaan pajak tanpa menambah beban baik jenis pajak baru maupun persentase pajak yang sudah ada kepada masyarakat, dunia usaha dan para pekerja adalah melalui program pengampunan pajak, atau yang lebih dikenal masyarakat dengan sebutan tax amnesty. Salah satu tujuan pengampunan pajak ini adalah dapat mengurangi citra negatif pada aparat perpajakan yang selalu dipersepsikan bersikap sewenang-wenang dan selalu dihindari, berubah menjadi hubungan yang lebih "friendly". Pada dasarnya inovasi ataupun upaya ini dapat diterapkan di Indonesia.

Keunggulan yang diharapkan dari kebijakan tax amnesty ini dapat mendorong masuknya dana-dana masyarakat baik dari luar negeri maupun dalam negeri yang dalam jangka panjang dapat digunakan sebagai pendorong investasi yang pada gilirannya bermanfaat untuk menstimulasi perekonomian nasional.

Di sisi lain kelemahannya pengampunan pajak adalah tidak serta merta menjamin kinerja setoran pajak ke kas negara. Maka dari itu, untuk meminimalisir kelemahan yang ada Direktorat Jenderal Pajak mengeluarkan peraturan Dirjen Pajak Nomor 11/PJ/2016 tentang Pengaturan Lebih Lanjut mengenai pelaksanaan Undangundang Nomor 11 Tahun 2016 tentang Pengampunan Pajak (Tax amnesty). Peraturan baru DJP ini dibuat agar masyarakat memiliki azas keadilan bagi masyarakat. Aturan ini diharapkan dapat memperjelas aturan sebelumnya yang dinilai meresahkan masyarakat.

"Ini merupakan azaz keadilan, karena sekarang masyarakat sangat antusias ikut tax amnesty. Karena, kalau keresahan yang muncul, itu pasti akibat ada aturan yang belum jelas," jelas Direktur Jenderal Pajak Kementerian Keuangan, Ken Dwijugiasteadi. Dengan adanya peraturan DJP Nomor 11/PJ/2016 ini diharapkan bisa menghindari kekeliruan tertang tax amnesty. Dengan adanya peraturan ini juga diharapkan tidak mengulang kegagalan penerapan tax amnesty seperti di tahun 1964 dan tahun 1984 yang gagal karena minimnya akses informasi terhadap masyarakat dan minimnya keterbukaan/transparansi serta sosialisasi kebijakan ini.

\section{Analisis ImplementasiTax amnesty}

Bila dianalisis terutama dilihat dari sisi kekuatan, kelemahan, peluang, dan tantangan implementasi penerapan Tax amnesty, dapat dijelaskan sebagai berikut.

\section{Strength (Kekuatan)}

Sumber daya yang dimiliki pada instansi aparatur pajak saat ini sudah memadai dan dirasa sangat ideal untuk mendukung diberlakukannya penerapan tax amnesty. Demikian juga infrastruktur pendukung lainnya. Tercatat pegawai Direktorat Jendral Pajak saat ini adalah kurang lebih sebesar 61.000 orang, sehingga bila wajib pajak berjumlah 30,5 juta orang berarti rationya adalah $1: 500$. Rasio tersebut bisa dibilang sudah 
ideal, walaupun kedepannya perlu untuk ditambah lagi mengingat wajib pajak setiap tahunnya mempunyai tren meningkat.

Kebijakan tax amnesty yang diterapkan akan menciptakan kerelaan masyarakat untuk mendaftarkan diri menjadi Wajib Pajak dan menunaikan kewajiban perpajakan nya. Dengan adanya kerelaan masyarakat untuk mendaftarkan diri menjadi wajib pajak, dirapkan bisa meningkatkan jumlah dari masyarakat yang taat akan pajak. Pada saat ini kondisi ekonomi nasional Negara Indonesia relatif stabil dengan rata-rata pertumbuhan ekonomi di atas 5\%. Hal ini menjamin pemberlakuan tax amnesty tidak gagal seperti di tahun 1964 dan 1984.

Adanya payung hukum baru yaitu peraturan Peraturan Pajak Nomor 11/PJ/2016 tentang Pengaturan Lebih Lanjut mengenai pelaksanaan Undang-undang Nomor 11 Tahun 2016 tentang Pengampunan Pajak (Tax amnesty). Aturan ini dibuat, agar masyarakat memiliki azas keadilan bagi masyarakat.Aturan ini juga diharapkan dapat memperjelas aturan sebelumnya yang dinilai meresahkan masyarakat.

\section{Weakness (Kelemahan)}

Pernah dilaksanakan implementasinya. Pertama, pegampunan pajak sudah dilaksanakan pada tahun 1964 melalui Penetapan Presiden RI No. 5 tahun 1964 tentang Peraturan Pengampunan Pajak yang kemudian secara berturut-turut diikuti Kappres No. 26 tahun 1984 tentang Pengampunan Pajak. Keputusan Menteri Keuangan No. 966/KMK.04/1983 tentang Faktor Penyesuaian untuk Perhitungan Pajak Penghasilan. Namun efektifitas pelaksanaan tax amnesty tersebut masih rendah, efektifitas ini terukur dari rendahnya partisipasi tax amnesty tersebut.

Reformasi dan penataan sistem perpajakan sedang dan terus dilakukan pengembangan baik perbaikan potensi, intensifikasi dan ekstensifikasi, pengembangan teknologi informasi, perbaikan sumber daya manusia serta pengawasan. Oleh karena itu kemungkinan hasil akhir dari tax amnesty ini masih belum optimal. Padahal idelnya tax amnesty dilakukan sekali.

\section{Opportunity (Peluang)}

Program ini diharapkan dapat meningkatkan dana-dana masuk ke Indonesia yang cukup banyak di simpan di luar negeri. Di samping itu, dana-dana yang selama ini diparkir di luar negeri dapat kembali masuk ke tanah air bila pemerintah secepatnya menerapkan pengampunan pajak. Potensi dana yang mengalir diperkirakan berkisar US\$ 20-40 miliar atau setara Rp 360 triliun. (Data Kadin, 2009) Dana tersebut disimpan di sejumlah bank di Singapura dan Australia.

Sejumlah negara telah sukses memberlakukan tax amnesty, salah satu diantaranya adalah Afrika Selatan,, Korea Selatan dan India. Tingkat kepercayaan masyarakat yang masih tinggi merupakan salah satu peluang untuk mewujudkan tujuan akhir guna mengamankan penerimaan negara dari sektor pajak. Kondisi ekonomi Indonesia selama ini yang selalu membaik memberikan kesempatan untuk dapat diterapkannnya kebijakan tax amnesty.

Tax amnesty dapat berpengaruh positif bagi pasar uang pada Bursa Efek Indonesia. Bila kebijakan ini diterapkan maka mempunyai potensi terjadi penambahan emiten baru karena perusahaan-perusahaan tidak perlu khawatir atas permasalahan pajak yang telah lewat. Karena masalah perpajakan merupakan salah satu faktor yang dianggap memberatkan bagi calon emiten untuk mengubah status perusahaannya menjadi perusahaan terbuka. 
Tax amnesty dan Implementasinya

Bila program tax amnesty berhasil diimplementasikan maka pemerintah mempunyai beberapa keuntungan antara lain pemerintah dapat mengkonsentrasikan atau memfokuskan pada upaya pemberantasan korupsi. Demikian juga dengan diimplementasikan tax amnesty maka asset recovery-nya lebih mudah karena tidak perlu melakukan penyelidikan, penyidikan, penuntutan dan proses hukum lainnya untuk mengambil asset koruptor. Asset recovery adalah perbandingan antara jumlah kerugian negara yang didakwakan dengan penyitaan asset atau pengembalian asset korupsi. Selama ini persentase asset recovery masih relatif kecil. Persentase asset recovery dapat dijadikan acuan penentuan tarif tax amnesty.

\section{Treat (Tantangan)}

Salah satu tantangan yang dihadapi Direktorat Jenderal Pajak antara lain terus dikembangkan hubungan kerja sama internasional baik dengan institusi negara-negara lain maupun lembaga keuangan internasional untuk dapat saling tukar menukar data dan informasi perpajakan.

Beberapa peristiwa penyimpangan di Ditjen Pajak seperti "Kasus Gayus" berakibat pada penggiringan opini wajib pajak untuk memboikot pembayaran pajak dengan melakukan penghindaran pajak (tax avoidance). Banyaknya permasalahan yang timbul terkait pengampunan pajak sehingga aturannyapun menjadi semakin kompleks oleh karenanya diperlukan aturan yang jelas yang tidak menimbulkan persepsi yang berbeda serta berbagai kepentingan.

Saat ini Indonesia masih memiliki permasalahan lain terkait peningkatan tax ratio penerimaan pajak terhadap PDB. Tax ratio Indonesia sampai saat ini masih rendah berkisar 12 persen bila dibandingkan dengan beberapa negara tetangga, sehingga kebijakan tax amnesty adalah salah satu upaya alternatif guna meningkatkan minat pembayaran pajak di kalangan masyarakat.

Pada tahun 2015 rasio perpajakan (tax ratio) terhadap produk domestik bruto (PDB) mencapai 10,88 persen. Angka ini lebih rendah dibandingkan tahun lalu yang mencapai 11,9 persen meskipun penerimaan pajak 2015 mengalami kenaikan. Dengan rendahnya tax ratio tersebut maka diperlukan upaya-upaya pemerintah guna peningkatan tax ratio tersebut yang antara lain berupa pemberian pengampunan pajak dalam jangka pendek serta diharapkan dalam jangka panjang terjadi peningkatan wajib pajak maupun penerimaan pajak. Beberapa Bank di negara lain tidak setuju jika dana nasabahnya yang berasal dari Indonesia dikuras habis jika diadakannya tax amnesty.

\section{PENUTUP}

\section{Implikasi}

Dalam hasil penulisan ini menunjukkan bahwa tax amnesty pada dasarnya sangat penting diterapkan, hal ini dikarenakan tax amnesty akan membantu peningkatan Wajib Pajak yang lambat laun akan meningkatkan penerimaan negara. Dengan adanya penerimaan dari kebijakan tax amnesty, pemerintah akan dipermudah dalam pelaksanaan pembangunan nasional.

Terdapat beberapa implikasi terkait dengan penerapan tax amnesty, antara lain: (1) Adanya peningkatan Wajib Pajak yang didorong adanya kebijakan pengampunan pajak, atau yang lebih dikenal dengan nama tax amnesty; (2) Adanya Peningkatan penerimaan pendapatan negara, yang disebabkan peningkatan Wajib Pajak karena adanya kebijakan tax amnesty; (3) Terkait dengan pembangunan nasional, adanya peningkatan 
penerimaan pandapatan negara karena pajak akan membuat pembangunan lebih berjalan lancar dan diharapan bisa mempermudah masyarakat dan meningkatkan kesejahteraan.

\section{Kesimpulan}

Dari pembahasan di atas ada beberapa hal yang dapat di simpulkan antara lain sebagai berikut: (1) Salah satu kelemahan Tax amnesty bila diterapkan di Indonesia adalah dapat mengakibatkan berbagai penyelewengan dan moral hazard karena sarana dan prasarana, keterbukaan akses informasi serta pendukung lainnya belum memadai sebagai prasyarat pemberlakuan tax amnesty tersebut; (2) Dengan adanya payung hukum baru yaitu peraturan Dirjen Pajak Nomor 11/PJ/2016 tentang Pengaturan Lebih Lanjut mengenai pelaksanaan Undangundang Nomor 11 Tahun 2016 tentang Pengampunan Pajak (Tax amnesty). Peraturan baru DJP ini dibuat agar masyarakat memiliki azas keadilan bagi masyarakat. Aturan ini diharapkan dapat memperjelas aturan sebelumnya yang dinilai meresahkan masyarakat.

\section{DAFTAR PUSTAKA}

Mardiasmo, Prof.Dr.MBA.,Ak. 2016. Perpajakan - Edisi Terbaru 2016.Yogyakarta : Penerbit ANDI.

NN. 2015. Amnesti Pajak. Diakses pada 22 September 2016, dari http://www.pajak.go.id/amnestipajak.

Peraturan Direktur Jenderal Pajak Nomor Per-11/PJ/2016 tentang Pengaturan Lebih Lanjut Mengenai Pelaksanaan Undang-Undang Nomor 11 Tahun 2016 tentang Pengampunan Pajak.

Peraturan Menteri Keuangan Republik Indonesia Nomor 118/PMK.03/2016 tentang Pelaksanaan UndangUndang Nomor 11 Tahun 2016 tentang Pengampunan Pajak.

Ragimun.2012. Analisis Implementasi Pengampunan Pajak (Tax amnesty) di Indonesia.Diakses pada 22 September 2016, dari www.kemenkeu.go.id/.../Analisis\%20Implementasi\%20Tax\%20Amnesty.

Susunan dalam Satu Naskah Undang-Undang Perpajakan. 2012. Kementerian Keuangan Republik Indonesia Direktorat Jenderal Pajak Kantor Wilayah DJP Bali

Undang-Undang Republik Indonesia Nomor 11 Tahun 2016 tentang Pengampunan Pajak.

Yasa, I Nyoman Putra, SE.,M.Si. 2015. Buku Ajar Perpajakan: Pengantar \& Konsep. Singaraja: Universitas Pendidikan Ganesha

Tama,Gede Mandirta, Pradnyani,Ida Ayu Gede Danika Esa.2016. Wirausaha Dan Keresahaan Atas Undang-Undang Nomor 11 Tahun 2016 Tentang Pengampunan Pajak.Proceeding TEAM FE Undiksha. Universitas Pendidikan Ganesha 